\title{
A ROMAN CATHOLIC VIEW OF POPULATION CONTROL*
}

\author{
Norman St. John-Stevas $\dagger$
}

In the popular mind, the Roman Catholic Church is widely identified with opposition to population-control measures and with repression of those who practice them or advocate their use. Like most generalizations, however, this onecontains elements of both truth and distortion, and the distinction can be discerned. only if one apprehends the Roman Catholic value system apart from the particular means that may be chosen to implement it. It is to an elucidation of this distinction. that this article has been directed.

\section{CONTRACEPTION}

The Roman Catholic Church has always condemned contraception and, despitethe changed attitude of other churches, maintains its traditional position. ${ }^{1}$ The Church Fathers, and later St. Thomas Aquinas, held contraception to be sinful and. contrary to scriptural teaching." Thus, St. Augustine declares that "intercourse even. with one's legitimate wife is unlawful and wicked where the conception of the offspring is prevented. Onan, the son of Juda, did this and the Lord killed him for it."3 This interpretation of the sin of Onan is not universally accepted. Somescholars have maintained that Onan was punished not so much for indulging in. coitus interruptus as for breaking the levirate law, which required a man to raise children to his brother's widow, so that she should not be left without a child and the tribe would continue. The punishment for breach of the levirate marriage law, however, is laid down elsewhere in the Old Testament. ${ }^{4}$ Apart from the Onan text, the Old Testament also contains the general injunction to "increase and multiply,"

- This article is based and draws upon Nornas St. John-Strevas, Birth Control and Public Policy. $40-78$ (1960).

+ A.B. I950, M.A. I954, Cambridge University; B.C.L. I952, M.A. 1955, Oxford University; Ph.D:. 1957, University of London; J.D.S. 1960, Yale University. Of the Middle Temple, Barrister-at-law, Blackstone and Harmsworth Scholar; Political Editor, The Economist. Author, OBscenity aNd THE LAw (1956); Walter Bagehot (1959); Women in Public Law (I957); Birth Control and Public Policy (1960); LIFE, Death, AND the LAw (to be published in r96r).

${ }^{1}$ See the various condemnations of the Holy Office-viz., May 20, I851; April I9, 1853; March 26, 1897; November 23, 1922 .

${ }^{2}$ St. Augustine, De nupt. et con. i, I5; Lombard, Sent. iv, d. 3 I; St. Thomas Aquinas, Summa Treor. II-II. I54:I. St. Paul, in a passage possibly referring to contraception, denounces women who. "exchanged natural for unnatural intercourse." Romans $I: 26$.

${ }^{3}$ St. Augustine, De adulterinas conjugiis II. xii.

"Deuteronomy 25:7-10: "The woman shall come to him before the ancients, and shall take off hisshoe from his foot, and spit in his face, and say: 'So shall it be done to the man that will not build: up his brother's house': and his name shall be called in Israel, the house of the unshod." 
but this passage is also open to varying interpretations. ${ }^{5}$ It has also been suggested that the slaying of Sarah's seven husbands by the devil was a punishment for their employment of contraception, but this seems unlikely, since the angel, when overcoming the reasonable reluctance of Tobias to marrying her, and so risking the same fate, refers to her as a virgin. ${ }^{6}$

Scriptural texts apart, the Roman Catholic Church has based its condemnation of contraception on the natural law. The nub of the Roman Catholic position is contained in canon law, where it is stated that the primary end of marriage is the procreation and education of children. ${ }^{7}$ Pius XI, in his encyclical on Christian Marriage, stressed the "unnatural" character of contraception: "since therefore the conjugal act is destined primarily by nature for the begetting of children, those who in exercising it deliberately frustrate its natural power and purpose, sin against nature and commit a deed which is shameful and intrinsically vicious." ${ }^{8}$ The Pope thus restated the traditional teaching of the Roman Catholic Church, basing his pronouncement on the doctrine elaborated by St. Thomas Aquinas. ${ }^{9}$

The Roman Catholic natural law tradition accepts as self-evident that the primary purpose of sexual intercourse is procreation and relegates as secondary such ends as fostering the mutual love of the spouses and allaying concupiscence. This conclusion is based on two propositions-that man by the use of his reason can discover God's purpose in the universe, and that God makes known his purpose by certain "given" physical arrangements. Thus, man can deduce that the purpose of sexual activity is procreation-the continuation of the human race-and the physical arrangements God has provided may not be supplanted at man's will. We now know that not every act of coitus is conceptual, and Roman Catholic theology recognizes that some coital acts are conceptual and relational, others relational only. But to recognize this fact is not to conclude that acts may be rendered conceptual or nonconceptual at man's will. Man is free to act only within the pattern imposed by nature.

It is frequently objected that this argument from "nature" is inconclusive, since in other matters, nature is not allowed to run its course. Beards are shaved, fingernails are cut, rivers dammed. Roman Catholics do not suggest that such activities are immoral. Why, therefore, should they in the single case of sexual relations equate unnatural with immoral? To this objection, Roman Catholics answer that there is no purpose perceived by reason in allowing hair or nails to grow to inordinate

\footnotetext{
${ }^{5}$ Genesis $1: 28,8: 17,9: 7$.

Tobias $3: 8,6: 22$. The reason given for the death of the husbands is that they were among those "who in such manner receive matrimony, as to shut out God from themselves, and from their mind, and to give themselves to their lust, as the horse and mule, which have not understanding, over them the devil hath power." Id. 6:17. For a discussion of the text, see Gruenthaner, The Book of Tobias and Contraception, 8 Catrolic Biblicaz Q. 98 (1946), who concludes that the text does not refer to contraception.

${ }^{7}$ Canion Ior3.I.

${ }^{8}$ Pius XI, Casti connubii-On Christian Marriage (Encyclical No. 4, Dec. 3r, 1930), in Ternence P. Mclaughlin (Ed.), The Church and the Reconstruction of the Modern World-The Social ENCyclicals of POPE PIUs XI, at 115, 135-36 (r957) [hereinafter referred to as Casti connubii].

${ }^{\circ}$ St. Thomas Aquinas, SuMma Theol. II-II. $154: 1$.
} 
length or rivers to flow always in the same channels. The chief purpose of sexuality, on the other hand, is undeniably reproduction. Some Roman Catholic writers, however, have accepted this objection to the condemnation of contraception, pointing out that the argument is not universally applicable. ${ }^{10}$ They still condemn contraception as contrary to natural law, but on the grounds of its eventual harmful effects on the race rather than on its perversion of a faculty. However beneficial a contraceptive act may be in the individual case, it must be condemned, for if raised to a general line of conduct, evil results would inevitably follow.

The somewhat stark Augustinian-Thomist approach to marriage, with its emphasis on its social and procreative purpose and virtual disregard of the personal factors of friendship and love between the partners, has been challenged by a number of Roman Catholic writers and rejected as inadequate. ${ }^{11}$ They would like to see stress laid on the personal aspects of marriage, its role in increasing mutual love and perfecting the personalities of the spouses. To further this aim, the traditional terminology of "primary" and "secondary" ends should be abandoned. Dr. Herbert Doms, in his book entitled The Meaning of Marriage, denies that the constitution of marriage consists in a subservience to a purpose outside the spouses, for which they marry: ${ }^{12}$

It consists in the constant vital ordination of husband and wife to each other until they become one. If this is so, there can no longer be sufficient reason, from this standpoint, for speaking of procreation as the primary purpose (in the sense in which St. Thomas used the phrase) and for dividing off the other purposes as secondary.

The meaning of marriage is the community of life between the spouses, of which the child is the fruit and visible embodiment. This approach, claim its supporters, does not diminish the importance of the child in marriage, but stresses it in a different way. It is peculiarly apposite at a time when many seek to explain man in purely physiological terms, and it brings theology up to date by taking into account a whole range of biological and psychological data of which scholastic theologians were unaware. It is helpful in disposing of the problems raised by sterile unions, virgin marriage, and the practice of periodic continence.

Pius XI seems to have foreshadowed this view to some extent in his encyclical on Christian Marriage: $:^{13}$

${ }^{10}$ See Breen, Neo-Malthusianism: A Critique of Its Critics, in IRIsh Ecclesiastical Record 467 (193I); Mahoney, "The Perverted Faculty" Argument Against Birth Prevention, 79 Ecci.esiasticar Rev. I33 (1928). Cf. id. at 408 and 527. One example might be "chewing gum," which employs the natural faculties of the salivary glands and frustrates their purpose, yet is not considered immoral.

${ }^{11}$ See Districh von Hilderbrand, Die Metaphysik der Gemeinschaft [The Metaphysics of Comagunity] (1930); Herbert Doms, Sinn und Zweck der Ehe [Sense and Purpose of Matrimony] (I935); Bernardine Krempel, Die Zweckfrage der Ehe in neuer Beleuchtung [The Question of The purpose of Matriajony in a New Light] (I94I); Lavaud, Sens et fin du mariage: La thèse de Doms et sa critique [Direction and Purpose of Marriage: The Thesis of Doms and Its Critique], 44 RevoE Thomiste 737 (1938).

${ }^{13}$ Herbert Doms, The Meaning of Marriage 87 (1939).

${ }^{13}$ Casti connubii 126. 
This mutual inward moulding of husband and wife, this determined effort to perfect one another, can in a very real sense, as the Roman Catechism teaches, be said to be the chief reason and purpose of matrimony, provided matrimony be looked at not in the restricted sense as instituted for the proper conception and education of the child but more widely as the blending of life as a whole, and the mutual interchange and sharing thereof.

While retaining the traditional doctrine of the ends of marriage, the Pope is taking into account the motives of the parties, which in most cases will be based on mutual love rather than on a desire to have children. Dr. Doms and his followers have had a profound influence on contemporary Roman Catholic writing on marriage and have concentrated the attention of religious writers on the hitherto neglected "secondary" ends of marriage, of the complexity of which theologians are now much more aware. They have not, however, secured the abandonment of the traditional terminology. Had they done so, the way might possibly have been opened for the acceptance by the Roman Catholic Church of contraception in certain limited circumstances, and it was perhaps this fear that lead to an ecclesiastical censure for Dr. Doms's book and a categorical reassertion of the primary and secondary ends of marriage in a Vatican decree of $1944^{14}$ Dr. Doms's views do not, however, lead inevitably to this result. Even if relational and conceptual ends of marriage are placed on an equal basis, the condemnation of contraceptives is not excluded, for coitus can still be treated as a given act, the intrinsic nature of which is the giving and receiving of seed. Unless it is this, then neither its conceptual nor relational ends are achieved, and it becomes an onanistic act of self-love, ontologically distinct from true coitus.

Roman Catholics employ a number of subsidiary arguments in their condemnation of contraception. It has, they maintain, certain harmful effects on personal and social health, which are the inevitable result of disregarding natural law. First, the health of the woman suffers, for she needs certain vital substances contained in male semen, and absorption of these is greatest from the womb. ${ }^{15}$ Contraception may be a contributory factor in causing cancerous growths, and cancer of the breast is more common amongst sterile married women than in those who have borne children.10 It is said that the use of contraceptives induces sterility, and one physician, not a Roman Catholic, has maintained that it causes lunacy. ${ }^{\mathbf{1 7}}$ By interfering with the consequences of pregnacy, it may cause neurasthenia and an unsatisfied sex craving that leads to overindulgence and destroys matrimonial harmony. These views are supported by a substantial body of medical opinion, but there is also weighty

\footnotetext{
14 The following question was addressed to the Holy Office: "Can the opinion of certain recent writers be admitted who either deny that the procreation and education of offspring is the primary end of marriage, or teach that secondary ends are not essentially subordinated, but equally principal and independent?" Reply: Negative. 36 Acta Apostolicae Sedis I03 (I944).

${ }^{25}$ See Harliday Sutherland, Laws of Life $4 \mathrm{r}$ (1935).

18 Id. at 47.

${ }^{17}$ For the lunacy statement by Sir Robert Armstrong-Jones, see Edward Moore, The Casz Against Birth Control 28 (I93 I). For a full discussion of the harmful medical effects of birth control, see R. DE Guchteneere, Judgment on Birth Controt 135-64 (r93I); Moore, op. cit. supra at 2x-31; E. Podvin, A Doctor Speaks Out on Birth Control (1937).
} 
authority that rejects them. Thus, the Biological and Medical Committee of the Royal Commission on Population concluded that the methods generally in use in England for preventing conception caused no injury to the genital passages, if employed in accordance with instructions, and added that there was no evidence that birth-control methods approved by the medical profession impaired fecundity. ${ }^{18}$ Other doctors point to the beneficial effect on a mother's health when she is relieved from the prospect of endless pregnancies, and the dangers of pregnancy to women suffering from tuberculosis, diabetes, nephritis, or heart disease. Birth control has the negative virtue that it prevents recourse to abortion, which is far more dangerous. ${ }^{10}$

Roman Catholics further stress that the use of contraception leads to population decline, and the truth of this is now firmly established. The Royal Commission on Population concluded that the decline in the birth rate in England was not due to a fall in reproductive capacity, but to the spread of deliberate family limitation. ${ }^{20}$ Similar conclusions were reached by the French authorities, and in 1920, a law was passed in France outlawing sale of contraceptives in order to arrest population decline.

Whether population decline is an absolute evil is open to question. The high standard of living in western Europe and the United States could never have been obtained without a massive growth in population, but it seems equally evident that increasing population is holding back living standards in many undeveloped parts of the world, especially in the Far East. ${ }^{21}$ A nation that fails to increase its population may have valid economic reasons for not doing so, but a nation that does not replace its population, provided living standards are adequate, may justifiably be regarded as in some respects decadent. The situation revealed by the Royal Commission on Population, that the British nation is no longer replacing itself, the deficiency being in the region of six per cent, is certainly alarming, especially when the need of the Commonwealth for immigrants is considered. ${ }^{22}$ The prospect of a rapidly aging population supported by an ever-diminishing portion of younger people is not encouraging. As the Royal Commission mildly concluded: "It is possible that with

${ }^{18}{ }_{4}$ Papers of the Royal Commission on Population paras. 46, 52 (1950).

${ }^{10}$ Royal Commission on Population, Report, CMD. No. 7695, at 159 (1949) [hereinafter cited as Report]: "Our survey of the history of family limitation leaves us in no doubt that, if these methods were not available, other means would be used, and some of them, e.g., criminal abortion, the prevalence of which is even now distressingly high, are very undesirable."

${ }^{20}$ Report para. 626.

32 See Report para. 60 et seq.

${ }^{22}$ Report para. 626. The Report found that 2.2 is the average size of the British family. " $A$ further spread of the practice of family limitation, and a continued improvement in its effectiveness, must be expected to take place and will tend to reduce average family size, but only slowly." Id. para. 630. The British birth rate has, in fact, increased from $16 . x$ in 1950 to 16.5 in $195 \%$. An optimistic view was expressed by Professor P. B. Medawar in the first Reith lecture for r959 on The Future of Man. "As for replacement," he said, "I do not know that any demographer, on present evidence, now fears a serious decline in the population of Great Britain. The latest estimates suggest that we are just about breaking even. ... In so far as purely biological pressures can influence marriage rates and ages, I guess that the present upward turn may be genuine and not just temporary." 62 THE LisTener 863, 865 (I959). 
a diminishing proportion of young people the community might lose something in energy, initiative, enterprise, and other qualities associated with youth."23

Contraception, Roman Catholics maintain, is corrupting to the individual, since it reduces self-control and its employment in the majority of cases will be for selfish reasons. Marriage will be degraded to a legalized form of prostitution. Furthermore, contraceptives undermine public morality by removing the fear of pregnancy, which is a powerful deterrent against promiscuous intercourse. ${ }^{24}$ An argument for employing contraceptives can be made for particular cases, but once they are made generally available, no means exists of restricting their use to these cases.

These Roman Catholic arguments are countered by those favoring contraception with a list of benefits accruing from its employment. It prevents overpopulation, avoids the birth of unwanted children, reduces infant mortality and juvenile delinquency, safeguards the mother's health, and facilitates early marriage. The argument on this level, however, tends to be artificial. Sociological arguments are employed by Roman Catholics mainly for polemic purposes and as a gloss to illustrate the argument from natural law. Moreover, now that Roman Catholic theologians have sanctioned the use of the safe period as a legitimate method of birth control, a number of the arguments have lost their force. Underpopulation or promiscuity might well result from a wide dissemination of knowledge of the arithmetic of periodic continence. The Roman Catholic attitude to the safe period may here be conveniently considered at greater length.

For centuries, doctors have speculated about the possibility of a sterile period in women, but until this century, no reliable means was available to calculate its duration. In I930, however, two doctors, Dr. Ogino of Japan, and Dr. Knaus of Austria, working independently, published the results of their researches, which though differing in detail, indicated the same method of calculating the length of the period. ${ }^{25}$ During a woman's menstrual period, ovulation occurs only once, the ovum or egg being discharged from an ovary into the fallopian tubes. Conception can only take place at this time and for a short time thereafter. Once a woman's particular pattern has been established by careful observation, therefore, a formula can be worked out that will indicate her sterile period.

Use of this method to control conception has a number of advantages: it involves no mechanical contrivance and allows physiological union; it avoids the risk of

${ }^{23}$ Report para. 647 .

${ }^{2}$ This contention is borne out by the data available. Kinsey found that in his sample of 5,700 women, fear of pregnancy ranked third in the factors deterring them from premarital intercourse. Eighty-nine $\%$ cited moral objections, $45 \%$ lack of desire, $44 \%$ fear of pregnancy, $44 \%$ fear of discovery, $22 \%$ lack of opportunity, and $14 \%$ fear of disease. Alfred C. Kinsey, Wardeil B. Pomeroy, Clyde E. Martin \& Paul H. Gebhard, Sexund Behavior in the Human Female 332 (1953). Among college women, investigators have found that fear of pregnancy ranks as a primary factor- $50 \%$. D. D. BrosiLEY \& F. H. Britten, Youth and Sex: A Study of 1300 College Students (1938).

${ }^{25}$ Ogino, Über den Konzeptionstermin des Weibes und Seine Anwendung in der Praxis [On the Time of Conception of the Female and Its Application in (Medical) Practice], 56 ZBL. F. Grv. 721 (1932); Knaus, Die periodische Frucht-und Unfruchtbarkeit des Weibes [The Periodical Fertility and Infertility of the Female], 57 ZBL. F. Gyn. 1393 (1933). See Tietze, The Current Status of Fertility Control, supra pp. $426,430-31$. 
physical injury that appliance methods may cause; and it demands the exercise of a degree of self-control. On the other hand, it has obvious disadvantages: first, it can only be used after a period of extended observation and the help of a competent physician; even after the most careful observation, a woman can easily make an error of calculation in using her chart; ovulation exceptionally may take place on unpredicted days or may be brought on prematurely by sexual intercourse; an emotional disturbance may upset the menstruation cycle, and after pregnancy a considerable time may elapse before the cycle returns to stability; and it requires absolute continence on certain days, and some married couples may find this almost impossible.

An alternative method of fixing the date of ovulation is a basal body temperature chart. Directly after ovulation, the basal or lowest normal daily temperature rises and remains at the higher level until shortly before the next period of menstruation. Here, again, previous observation of the temperature pattern for a considerable period is necessary, and obviously mistakes can be easily made. Furthermore, the method provides no protection against conception resulting from intercourse in the two or three days before ovulation has taken place. On the other hand, by combining this method with that of Ogino-Knaus, the number of days on which intercourse must be restricted can be reduced, and this is of especial importance where there is a wide variation in the menstrual cycle.

Yet another method of fixing the time of ovulation has recently been evolved. In order to nourish the egg, the womb secretes sugar, and this sugar is only present at the time of ovulation. When the egg dies, the sugar disappears. A piece of chemically prepared tape held against the womb will turn green if the sugar is present and will remain neutral if it is not. A period of four days' abstention after the tape shows green is advised. ${ }^{26}$ Experiments are also proceeding to develop a drug that will stabilize the menstrual period, and this would be especially helpful for women with highly irregular periods.

Various studies have been undertaken to ascertain the effectiveness of the rhythm method of birth control in practice. In an investigation carried out by the St. Louis University Department of Sociology, two-thirds of the doctors who replied to a questionnaire thought the method was not too complicated for most women. ${ }^{27}$ As to its effectiveness, opinion was very divided, ranging from estimates of five per cent to Ioo per cent, the midpoint in the distribution of estimates being seventy-one per cent..$^{28}$ An investigation of women using the rhythm method at the Free Hospital

${ }^{30}$ N.Y. Times, April 24, 1958, p. 26, col. I.

${ }^{97}$ Schnepp \& Mundi, What Doctors Think of the Rhythm Method, 123 Ax. Ecclessisticar Rev. III (1950). The questionnaire was sent to 523 physicians, of whom 273 replied. Roman Catholic doctors comprised $39 \%$. For an estimate of $100 \%$ effectiveness, see Latz \& Reiner, Further Studies on the Sterile and Fertile Periods in Women, 43 AM. J. Onstet. \& Gmecol. 79 (1942).

${ }^{29}$ Schnepp \& Mundi, supra note 27 , at I $_{4}$ : "Of the 192 doctors, 171 or about 89 per cent checked this question, and their opinions ranged from 5 per cent to roo per cent effectiveness. Taking the average of all estimates, or the mean, we found it to be 65.1 per cent with a standard deviation of 25 per cent; the latter indicates a considerable spread of opinions. The median, or midpoint in the distribution of estimates, was 7 I per cent effectiveness." 
for Women at Brookline, Massachusetts, revealed that the risk of pregnancy was I4.4 for every hundred years of exposure. For women using contraceptives, the equivalent figure was six to seven. ${ }^{29}$ Other doctors have estimated that if the rules are strictly observed, the rate of failures is three for every hundred years of exposure. ${ }^{30}$

From the medical and other evidence available, one may reasonably conclude that while the safe period as a method of birth control does not merit the contempt with which it has often been dismissed by those advocating the use of appliances, it is by no means foolproof, and exaggerated claims on its behalf are not supported by fact. No contraceptive is wholly reliable, but in the present state of knowledge, the margin for error is greater in rhythm than in appliance control. The conclusions of Dr. Tietze and others seem justified when they write that the rhythm method offers a satisfactory degree of protection against unwanted pregnancy to ${ }^{31}$

rigorously selected and carefully instructed wives, who with their husbands are intelligent and strongly motivated. For others and for those to whom pregnancy would be dangerous, the effectiveness of the method in preventing conception is not considered adequate.

Despite its condemnation by St. Augustine, ${ }^{32}$ use of the rhythm method is now approved by the highest authorities in the Roman Catholic Church. ${ }^{33}$ Pius XII removed all doubt from the matter in two statements in $195 \mathrm{I}^{34}$ The Roman Catholic ideal is one of fertility, not of sterility, and all things being equal, a large family is probably considered preferable; but the Roman Catholic Church has not given its approval to indiscriminate breeding. Rather, the practice of family planning is enjoined as a duty, the dispute with contemporaries being confined to the means employed. The general consensus of theologians is that the deliberate use of the safe period as a means of family planning is morally indifferent, and that the morality of its employment will depend on the presence of certain circumstances. ${ }^{85}$

\footnotetext{
${ }^{30}$ Tietze, Poliakoff \& Rock, The Clinical Effectiveness of the Rhythm Method of Contraception, 2 Fertility \& Sterilitry 444 (I95I).

${ }^{30}$ Fleck, Snedecker \& Rock, The Contraceptive Safe Period, 223 N. ENG. J. MED. 1005 (1940).

31 Tietze, Poliakoff \& Rock, The Clinical Effectiveness of the Rhythm Method of Contraception, 2 Fertilitry \& Sterility 444, 449 (195x).

${ }^{32}$ St. Augustine, ON the Morals of the Manichaeans XVIII. 65.

${ }^{33}$ The statement of Pius XI in Casti connubii that married couples were not acting unnaturally if they exercised their right to intercourse "although on account of natural reasons, either of time or of certain defects, new life cannot be brought forth," is sometimes quoted as approving the deliberate use of rhythm; but strictly interpreted, it has reference only to such situations as sterile marriages and the lawfulness of intercourse during the safe period. Casti connubii $\times 37$.

34 Express approval to employment of the rhythm was given and the circumstances appropriate to its use discussed. See Addiess to Italian Catholic Union of Midivives, 43 Acta Apostolicae Sedis 835 (195I), and Address to National Congress of the Family Front, 43 Acta Apostouicae Sedis 855 (1951). For an appraisal of the statements, see Geraid Kelly, Medico-Moral Problems 29 (1956); Kelly, Official Statement on Rhythm, I9 LINACRE Q. 39 (1952).

${ }^{35}$ For a typical article representing the majority view, see Ryan, The Moral Aspect of Periodic Continence, 80 Ecclesiastical Rev. 28 (1948). For a contrary view, see N. O. Griese, The Morality op Periodic Continence (I943).
} 
Two indispensable conditions are that both parties to the marriage freely agree to its use and both are able to bear the strain that it may impose. In addition, there must be some serious reason for its employment. Pius XII said in $195^{1}:^{36}$

The matrimonial contract, which confers upon the parties the rights to satisfy the inclination of nature, constitutes them in a state of life, the state of matrimony. Now upon the parties who make use of this right by the specific act of their state, nature and the creator impose the function of providing for the conservation of the human race. ... It follows from this that to enter upon the state of matrimony, to make constant use of the faculty proper to it and only in matrimony allowable, and on the other hand consistently and deliberately, and without serious reason, to shirk the primary duty it imposes would be to sin against the very meaning of married life.

The extent of the duty to procreate the race will clearly vary with external circumstances, such as local population and economic conditions. Serious reasons justifying resort to rhythm will in most cases, however, be personal, and these may be financial, medical, eugenic, or social. ${ }^{37}$ In each case, the judgment whether to use rhythm must be conscientiously made by the married partners after a careful survey of the relevant circumstances.

\section{II}

\section{The Law}

Does Roman Catholic theology require that contraception be banned by law? As has been seen, it is unequivocally condemned as contrary to natural law, but one cannot conclude with some rigorists that the question is immediately answered in the affirmative, since all contraventions of natural law are not fit subject for legislation. Fornication, adultery, and lying, for example, are contrary to natural law, but civil sanctions are not advocated for such offenses. Nonphilosophic criteria must be applied before the question can be disposed of. A breach of natural law must be a fit subject for legislation and injure the common good substantially before it is forbidden by law. The law must be capable of enforcement and equitable in its incidence. Finally, if it would cause greater evils than those it is intended to avoid, recourse to legislation must be eschewed.

The banning of the use of contraceptives by law, as in Connecticut, fulfills none of these criteria. Using a contraceptive is essentially a private act, and though it may have harmful social consequences, it is impossible to isolate any particular act and demonstrate that harmful consequences flow from it. In practice, such a law is obviously unenforceable, and the attempt to enforce it would involve an intolerable interference with the private life of individuals. Private individuals and married couples would have to be subjected to constant supervision, the home would be invaded by investigators, and the police state advanced to a new point.

Banning the sale of contraceptives and the dissemination of birth-control information, on the other hand, is a possible subject for legislation, since these are

${ }^{30}$ Pius XII, Address to Italian Catholic Union of Midwives, 43 ACTA Apostourcae Senis 835 (I95I).

${ }^{37}$ For a discussion of serious reasons, see John L. Thomas, Marriage and RhythM 85-112 (I957). 
public acts, capable of regulation by law. Certainly such laws are difficult to enforce, but their effect would be far from nugatory, given a climate of moral opinion that approved their content. Thus, in a predominantly Roman Catholic country, such laws would not be unreasonable, and they are found in countries such as Spain, Italy, and Ireland ${ }^{38}$ It might, of course, be maintained that moral condemnation renders a law superfluous, but this view is unrealistic, since law is closely connected with the moral opinion of the community and is a powerful, although subsidiary, means of maintaining moral standards.

Some would condemn such laws on abstract grounds-namely, that they violate the freedom of the individual to make his own choice. But on this abstract level, the argument would not appeal to Roman Catholics, who maintain that there can be no right to commit an immoral action. Nor would the contention that condemnation of contraception is a specifically Roman Catholic doctrine fare better, since Roman Catholics hold that the prescripts of natural law are binding on all men, and the Roman Catholic Church herself is powerless to change them. Protestants and others often argue that to allow the sale of contraceptives in no way diminishes Roman Catholics' rights, since they are under no obligation to use them. In a certain sense, this is true, but a society in which contraceptive sales and propaganda are unfettered clearly exerts a strong pressure on its members to use them or at least makes it more difficult for them to abstain from their employment. ${ }^{30}$ The plain fact is that if religion is more than a purely personal and private exercise, if it sets out to provide a Weltanschaung, then it is bound to have social effects that may diminish the freedom of those who reject the faith. To expect a society in which the majority of its inhabitants condemn contraception as a moral and social evil to allow its unfettered spread in the name of a doctrine of abstract right is to ask for the impossible. It is only because moral opinion in Britain and the United States accepts contraception as more or less a good that it is so largely uncontrolled.

Does Roman Catholic theology then oblige Roman Catholics in non-Roman Catholic countries, and specifically in England and the United States, to work for such prohibitory laws or to defend them where they exist? Such a question can certainly not be answered by means of a logical deduction from a natural law

\footnotetext{
${ }^{38}$ In Spain, an Act of January 24, r94I, forbids any form of public instruction on methods of birth control and the exhibition or offering for sale of contraceptives. Customs regulations forbid the importation of contraceptives. Doctors, however, are not forbidden to prescribe contraceptives, but birth-control advice may not be given as part of any public health service and there are no birth-control clinics. The laws appear to be effective.

In Italy, birth-control propaganda is forbidden, but sale of contraceptives is allowed in pharmacies. No birth-control clinics exist, and contraception may not be advised by those discharging public health service duties.

In Ireland, The Censorship of Publications Act, 1929, No. 21, forbids the writing or publication of matter "which advocates or might reasonably be supposed to advocate the unnatural prevention of conception." An Act of July 31, 1920 forbids the divulging of methods of contraception, etc.

${ }^{39}$ This point is illustrated unintentionally by those who produce evidence of Roman Catholics who attend birth-control clinics as part of the argument for lifting legal bans. In fact, 'as has been recorded, while Roman Catholics in the United States do use contraceptives, they do so less than non-Roman Catholics. See, e.g., Norman E. Himes, Medical History of Contraception 4I4-i6 (I936).
} 
premise, but the particular social situation in the country under consideration must instead be carefully examined. By the constitution and political philosophy of both England and the United States, Roman Catholics certainly have a right to work for the passage of such laws, using all the normal political means, such as public campaigns, distribution of literature, and lobbying of legislators, to attain their end. By such means in the past, laws restricting gambling, betting, and drinking have been added to the statute book, but not by Roman Catholics. Indeed, they reject the doctrinal suppositions that these laws embody and might argue that their personal freedom was unfairly diminished. The right then exists, but whether Roman Catholics would be wise to follow Protestant precedent and exercise it is open to considerable doubt.

Laws embodying moral precepts are only enforceable if they are supported by a corresponding moral consensus in the community. The Volstead Act should have made this plain enough. A law forbidding the sale of contraceptives would be effective only if the vast majority of citizens believed their use to be wrongful, and possibly not even then. The laws of Connecticut and Massachusetts on birth control are not, in fact, enforceable, and save for the exclusion of birth-control clinics, are without effect. Even here, the presence of clinics over the state lines does much to neutralize their exclusion from the states themselves. Roman Catholics, then, in campaigning for the maintenance of such laws, gain little for public morality. They do, however, increase the fear of Roman Catholicism in the minds of non-Roman Catholics and increase the likelihood that when Protestants visualize the Roman Catholic Church, the image will be not that of a religious body, but that of a political power structure. This is a high price to pay for the maintenance of ineffectual statutes. The argument from natural law is unconvincing, since outside the Roman Catholic Church, even those who accept the concept of natural law are unable to see that it forbids birth control. While without bearing on the truth or falsity of the natural law premise, an almost universal scepticism should be treated as relevant when a policy of enforcing the precept by means of civil legislation is considered.

Aside from metaphysics, Roman Catholics could justify a prohibitive law if they could show that demonstrable evils flow from the practice of contraception. If a declining population and a falling standard of life could be traced directly to birth control, then a strong case would have been made out for banning it. On these grounds, birth control has been banned in France, the law being inspired by imperial and sociological rather than theological reasons. ${ }^{40}$ In England, a similar situation might come about in the foreseeable future; but in the United States, such a contingency is remote. ${ }^{41}$ Again, if contraceptive methods could be shown to be harmful to health, a prohibitory law might be justified, but as has been noted, the evidence

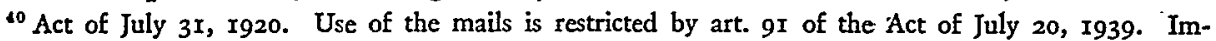
portation of contraceptive propaganda, etc., is restricted by an Act of February 5, 1946. No birth-control clinics operate, nor is advice given, under public health services. Exemptions exist for doctors to prescribe contraceptives, such as the danger to a mother's health from further pregnancies.

"1 The United States birth rate is high; the rate of 24.9 per 1000 in 1954 having increased to 25.0 in 1957. See U.S. Bureau of the Census, Dep't of Commerce, Statistical Abstract of the U.S.A. table $56(1958)$. 
on the point is conflicting and allows no such conclusion. Finally, the argument that recourse to contraceptives increases lust and promiscuity would, if established, give grounds for a ban, but increase in such vice is not measurable and, if it were, could not be conclusively demonstrated to result from contraception.

In summary, then, one may say, that while the prophetic mission of the Roman Catholic Church to judge and if necessary condemn society is not questioned, a strong case exists for the abandonment of Roman Catholic efforts to secure a total legislative ban on contraceptives. Efforts to preserve public morality would be more constructive if confined to measures commanding general support, such as the banning of sales of contraceptives from slot machines or the restriction of salcs to adults. ${ }^{42}$ Statutes regulating contraception belong more appropriately to the field of public nuisance than to the criminal law proper.

Roman Catholics might also legitimately and prudently oppose laws that in any way commit the state to approve or advocate birth control. Two events in the United States during I959 raised this issue sharply. In July 1959, the Draper Committee, appointed to study the foreign aid program, submitted its Third Interim Report to the President. ${ }^{43}$ With the Report went a covering letter stating that the Committee recommended that, when requested by aid-receiving nations, the United States should help them to formulate programs "to deal with the problem of rapid population growth and should support research leading to better understanding of this problem." Mr. Draper agreed with reporters that this reference included the provision of birth-control information by the United States, but added hopefully that the point should not be unduly stressed. ${ }^{44}$ In September 1959, the issue was raised again when the Senate Foreign Relations. Committee published a study by the Stanford Research Center recommending that the United States should study the possibility of backing large-scale foreign tests of birth-control devices. ${ }^{45}$

In November 1959, a reaction came from the Roman Catholic Bishops of the United States, who announced they would fight any attempt to use foreign aid funds to promote "artificial birth prevention programs" in underdeveloped countries. Condemning such programs as a "morally, humanly, psychologically, and politically disastrous approach to the population problem," they stated that the logical answer to world population problems was not to decrease the number of people, but to increase the food supply, "which is almost unlimited in potential."46 This statement caused a political storm. Bishop James A. Pike, the Protestant Episcopal Bishop of

\footnotetext{
"2 Where a prohibitory law is impossible, a regulatory law may be desirable, even if it "recognizes" indirectly the existence of an evil.

${ }^{43}$ President's Coma. to Study Military Assistance Program and Administration, Third Interim REPORT (1959).

"Facts on' File, July 23-29, 1959, p. 240. The Report itself did not stress this point, rccommending the provision to requesting countries of "demographic information."

${ }^{2}$ Stanford Research Center, 86th Cong., ist Sess., United States Foreign Policy, Possidle Nommilttary Scientific Developments and Their Potential Impact on Foreign Policy Problems op the United States, a Study Prepared at the Request of the Senate Committee on Foreion Rela. TroNs (Comm. Print 1959).

4 The Times (London), Nov. 26, 1959, p. Io, col. 7 .
} 
California, condemned the statement and asked whether it was binding on candidates for public office. The reference was clearly to Senator Kennedy; one of the aspirants for the Democratic nomination in 1960 , who replied that he thought such policies would be mistaken since they would be interpreted as discriminatory. The United States has never urged them either at home or in western Europe. ${ }^{4 \tau}$ If faced with a bill embodying such a program, he stated he would judge the measure by whether "it would be in the interests of the United States." If it became law, he would uphold it. ${ }^{48}$

Senator Kennedy's replies were both judicious and constitutionally. correct. 'The Roman Catholic Bishops were also within their rights in making their statement, and it might well be taken as a guide for future Roman Catholic political activity in this area. This should be limited to securing government 'ileuttality on the issue, not an ideal objective, but one that recognizes an irreconcilable conflict of moral and social views within the community. ${ }^{49}$ The proposition that adoption of an artificial birth-control program should be made a condition precedent of receipt of foreign aid funds would, in any event, probably command little support. The supply of foreign aid funds at the request of an individual state in order to implement such a program would, on the other hand, be found unobjectionable' by' many. But just as Roman Catholics would be wise in recognizing the majority view and refraining from pressing for prohibitive domestic legislation, so the majority: favoring contraception would be judicious in refusing such requests and so recognizing the susceptibilities of the minority. To dub such a policy one of allowing the minority to dictate to the majority is to misstate the issue. It would be better described as a judicious recognition of the existence of a considerable minority opinion, the flouting of which would inevitably lead to serious diminution of civil peace. Reasonable concessions to such opinion offer a better as well as a more effective basis for the working of a democracy than the mechanical application of the principle that the will of the majority must always prevail.

III

\section{Some Cognate Problemis}

A. Tax-Supported Hospitals and Public Health Services

The giving of contraceptive advice in tax-supported hospitals or as part of public health services has caused sharp conflict between Roman Catholics and Protestants. Roman Catholics claim that since their money is being used to finance public institutions, practices that they consider immoral should not be followed. Protestants

${ }^{77} \mathrm{Mr}$. Stevenson and Senator Humphrey were in favor of providing information on request, only Senator Symington expressing himself unequivocally in favor of birth control. See American SurveyThe Next President, 93 The Economist 967 (1959).

${ }^{48}$ The Birth Control Isste, Time, Dec. 7, 1959, p. 22. No foreign aid money has, in fact, been spent on this objective.

"An example of a state government exceeding the bounds of neutrality occurred in Pennsylvania in December 1948, when the Board of Public Assistance approved a resolution permitting case workers to refer relief clients to birth-control information centers. See Pittsburgh Post-Gazette, Dec. 24, 1958, and Controversy in Pennsylvania, 69 Commonwesl 425 (1959). 
and others also claim that since their money is employed, practices that they consider morally acceptable should not be excluded by Roman Catholic veto. In England, advice on contraception may be given as part of a public health service, but is subject to restriction. In certain southern states in the United States, where Roman Catholics are few, such advice is given in health centers and hospitals, but in many municipally-financed hospitals in northern states, it is forbidden.

The issue came to a head in 1958 in New York, where for many years, city hospitals had followed an unwritten rule that advice on birth control should not be given. In July 1958, a Protestant physician, Dr. Hillman, employed at Kings County Hospital, announced that he was going to fit a Protestant patient with a contraceptive diaphragm, but he was forbidden to do so by Dr. Morris Jacobs, New York City Commissioner of Hospitals. A. public controversy followed, with Protestants and Jews demanding that the ban be lifted in the interests of accepted therapy and preventive medicine and the Roman Catholic Chancery Office stating: "It would be extremely unfortunate if our hospitals and medical faculties, aimed for the preservation of life, should be perverted to seek for the prevention of life." On September $\mathrm{I} 7$, I958, the full Board of Hospitals ruled in favor of Dr. Hillman and reversed the ban. The Board laid down that municipal hospitals "should provide such medical advice, preventive measures and devices for female patients under their care whose life and health in the opinion of the medical staff may be jeopardized by pregnancy and who wish to avail themselves of such health services." A certificate of medical necessity signed by two physicians must be issued, the consent of the patient, and that of her husband if possible, obtained, and the Board recommended a conference with her spiritual adviser. Physicians, nurses, and other hospital employees who have religious or moral objections to contraceptive procedures were to be excused from participation in contraceptive procedures. Later the same month, the New York Department of Welfare adopted a similar policy. ${ }^{50}$

The compromise seems reasonably satisfactory. Roman Catholic doctors and patients are in no way obliged to follow procedures violating their moral principles and religious beliefs, while non-Roman Catholics are assured that they will not be denied access to contraceptive medicine where this might endanger health. At the same time, the susceptibilities of Roman Catholic taxpayers are recognized by leaving general contraceptive advice to be given by voluntary agencies founded for that specific purpose. ${ }^{51}$

${ }^{50}$ For an account of this incident, see N.Y. Times, Sept. 17, 1958, p. 39, col. 5; $i d .$, Sept. 18,1958, p. I, cols. 2-3; id., Sept. 23, r958, p. I, col. 6 . Also see Controversy on Contraception, roo Ameruca 7 (1958); and for a comment, see Finn, Controversy in New York, 68 Commonweal 583 (1958). Sec also A. W. Sulloway, Birth Control and Catholic Docrnine r95 (1959); Sulloway, The Legal and Political Aspects of Population Control in the United States, infra pp. 593, 605-07.

${ }^{81}$ This compromise, because the factual situation is different, is not the same as that suggested in connection with the foreign aid program. The two situations are also theoretically distinguishable, since artificial birth-control facilities provided in municipal hospitals within these restricted limits do not commit the municipality to a policy of generally furthering birth control. The foreign aid program, on the other hand, is an act of policy involving the whole nation as such. 
B. Roman Catholic Hospitals

In Roman Catholic hospitals, birth-control advice, unless it relates to the practice of continuous or periodic continence, may not be given..$^{52}$ As an internal domestic matter, this raises no problem, but controversy has arisen over the position of doctors on the staff of Roman Catholic hospitals who have associated themselves with the work of birth-control organizations. Thus, in 1947, six Protestant physicians were dismissed from three Connecticut hospitals for their work-outside the hospitalfor the Planned Parenthood Federation. Again, in I952, St. Francis Hospital in Poughkeepsie, New York, presented seven Protestant physicians with an ultimatum to quit the Planned Parenthood Federation or resign from the hospital staff. Three agreed to resign from the Planned Parenthood Federation, but four declined and were suspended. After a number of protests, they were reinstated at the beginning of $1953 .^{53}$ Other Roman Catholic hospitals have sought to make it a condition of employment that doctors will not give birth-control advice, either in the hospital or in private practice. ${ }^{54}$

To require Protestant doctors employed in Roman Catholic hospitals to refrain from giving advice on birth control in the course of discharging their hospital duties is reasonable enough. A doctor is free to make a contract with any hospital, and if he objects to any specific term, he can make his services available elsewhere. But to extend hospital jurisdiction to private practice or to activities carried on outside the hospital in a personal capacity is a grave infringement of individual liberty. While there might be a case for excluding a Roman Catholic doctor who supported Planned Parenthood, because of the scandal his attitude would give to Roman Catholic patients and hospital personnel, the coercion of a Protestant doctor to go against his conscience is wrong in principle. It also betrays a confusion in practical aims. A Roman Catholic hospital is primarily a hospital and exists to give the best medical treatment available to its patients. If conditions such as that forbidding Protestant doctors to prescribe contraceptives outside the hospital were generally imposed, it would materially restrict the medical talent on which the hospital could draw. Apart from this, attempts to dominate a doctor's entire professional life will be generally construed as tyrannical and can only serve to embitter relations between the Roman Catholic and other local, religious, and civic communities.

${ }^{63}$ See Catholic Hospital Ass'n of the United States and Canada, Ethical and Religious DiReCtives for Catholic Hospitals No. 30, at 6 (2d ed. I957).

${ }^{53}$ Connecticut: see The Law in Connecticut, Time, April 21, 1947, p. 58; N.Y. Times, April 8, 1947, p. 24, col. 2; id., May 5, 1947, p. 25, col. 2. New York: see N.Y. Times, Feb. 8, 1947, p. 14, cols. 6-7; id., Feb. II, 1947, p. 28, col. 2; id., Jan. 22, 1953, p. 25, cols. 6-7. See also, for a similar incident at St. Joseph's Hospital, Paterson, N.J., Trowbridge, Catholicism Fights Birth Control, II2 NEw REPUBLIC 106 (1945).

"st. Elizabeth's Hospital, Newark, N.J., set such a condition in 1945. See Trowbridge, supra note 53, at 107 . 


\section{Civic Problems}

Roman Catholics often use local political pressure to counter birth-control organizations. Thus, in I952, the Planned Parenthood Federation was excluded from membership in the Welfare and Health Council of New York because the Roman Catholic agencies represented threatened to withdraw. Six months later, however, the Council voted for admission of the Planned Parenthood Federation, whereupon the Roman Catholic agencies resigned, thus handicapping the Council's work. ${ }^{55}$ In 1955, Roman Catholics boycotted the Princeton, New Jersey, Community Chest fund-raising campaign, thus compelling the withdrawal of the Planned Parenthood Federation from the Chest. ${ }^{58}$ Whatever one may think of the prudence of such actions, and this can only be judged in the context of local conditions, Roman Catholics are well within their democratic social rights in taking them. They hardly, however, seem "necessary," since membership in a cooperative enterprise does not imply approval of the constituent members. Furthermore, the line between legitimate and illegitimate social pressures can be easily crossed, as was the case in Holyoke, Massachusetts, in 1940, when owing to Roman Catholic pressure, Mrs. Margaret Sanger was deprived of a public meeting place to state her views, until one was provided at the last moment by the local textile workers' union. Such action was clearly against the spirit of the Constitution, with its guarantees of freedom of speech and the right to hold orderly public meetings. ${ }^{57}$ The hostility aroused against the Roman Catholic community by these tactics would be hard to overestimate; they strengthen in the non-Roman Catholic mind the ever-present fear of Roman Catholic power and do much to nullify the persuasive force of Roman Catholic teaching. In proportion to their ill effect, their good effect is small, and Roman Catholics would be well advised to abandon them.

\section{The Birth-Control Pill}

Experiments have been proceeding for some time to develop an oral means of contraception..$^{\text {s }}$ All women, when pregnant, secrete a natural hormone, progesterone, which prevents ovulation during the pregnancy period. A synthetic substitute for this hormone, progestin, has been developed, which has the same effect of inhibiting ovulation and can be taken by mouth. The drug has been used in tests carried out in Puerto Rico and California, and the Puerto Rican experi-

${ }^{5}$ See N.Y. Times, Jan. 15, 1953, p. 1, cols. 3-4; id., March 13, 1953, p. 25, col. 3; id., March 19, 1953, p. 29, col. I; id., May 8, 1953, p. 22, col. 2; id., May 29, 1953, p. 1, cols. 2-3; id., May' 30, 1953, p. I, cols. 2-3.

${ }^{56}$ N.Y. Times, Sept. I, r955, p. 25, col. 2.

${ }^{57}$ For a full description of Mrs. Sanger's experiences in Holyoke, see KENNETH UNDERwOod, Protestant and Catholic 3-38 (1957). The secretary of the local union' providing the hall was, in fact, a Roman Catholic. Roman Catholic pressure also caused the cancellation of birth-control exhibits at fairs in Chicago in 1940, N.Y. Times, July 8, 1940, p. 18, col. 4; and in New York in 1941. Id., Aug. 22, 1941, p. I7, col. 3 .

${ }^{58} \mathrm{~A}$ full account of progress and remaining difficulties is given in Millman \& Hartman, Oral Control of Conception-A Contemporary Survey, in Richard L. Meier, Modern Science and the Humisn Fertility Problex 218 (1959). 
ments have proved successful. The drugs have, however, produced bad side effects, such as nausea and dizziness, and have proved very expensive. Much remains to be done before they can be put on the market commercially. ${ }^{59}$ Another method of inducing temporary sterility has been suggested by Dr. Sieve of Boston, who has used phosphorylated hesperedin to form a viscous barrier around the ovum and so prevent penetration by the male sperm. While early experiments met with success, later ones failed. ${ }^{60}$ It has been suggested that such a drug would be acceptable to Roman Catholics, since it leaves the physical nature of the sexual act unimpaired, but Roman Catholic moralists have been unanimous in condemning the use of drugs as a violation of the divine law, since they prevent the natural end of the sexual act, procreation. ${ }^{61}$ The only justification for their use would be a medical rather than a contraceptive motive-e.g., relief from pain caused by menstruationwhen their employment would be justified on the principle of double effect. This principle, it may be noted, also justifies the sale of prophylactics, which while they may be used to prevent conception, are not sold with that purpose, but rather to prevent disease. Thus, their distribution to members of the armed forces would not be contrary to Roman Catholic moral teaching. ${ }^{62}$

\section{Christian Responsibility}

Since the end of World War II, experts first, and then the public in general, have been increasingly aware of the enormous problems created by the rapid rise in world population. "The problem of population," states Sir Julian Huxley, "is the problem of our age." ${ }^{\text {"63 }}$ Numerous monographs have been published on the consequences of the rise. The United Nations has carried out an important series of investigations into the causes and extent of the increase and in 1954 convened an international conference in Rome to exchange information. ${ }^{64}$ The magnitude of the

\footnotetext{
${ }^{80}$ See N.Y. Times, Sept. 19, 1958, p. 25, col. 5, where Dr. Rock reported figures of roo\% success for the experiments. These varied with the results reported in June by Edward Tyler and Henry Olson, which showed a 9.3\% rate ineffectiveness. See Shechan, The Birth Control "Pill", Fortune, April 1958, p. 154. See also The Times (London), March 3I, 1960, p. 7, col. 3, for an account of experiments in England that show that although a pill has been developed with a high degree of effectiveriess, harmful side effects persist.

"OSicve, A New Antifertility Factor, 112 Science 373 (1952).

${ }^{1}$ See The Use of a Sterilizing Drug, I22 AM. ECCLESIASTICAL Rev. 225 (1950); The Contraceptive Pill, 137 id. 50 (1957); Lynch, Fertility Control and the Moral Law, 20 LinaCre Q. 83 (1953). Use of pills to regularize a woman's menstrual cycle would not be contrary to Roman Catholic teaching. For a discussion of the moral problems raised by birth-control pills, see Calaghan, Fertility Control by Hormonal Medication, 27 Irish Theological Q. I (1960).

${ }^{03}$ For an expression of caution lest impression be given that prevention of disease is more important than avoidance of wrongdoing, see IRISH ECCLesIastical Recoro 83 (1942).

${ }^{03}$ Huxley, World Population, Scientific American, March 1956, p. 64 .

ot E.g., Political and Economic Planning, World Population and Resoukces, A Report (1955) [hereinafter cited as Worzd Population and Resources]; F. Le Gros Clark (Ed.), Four Thousand Mizlion Mouths (1951). See also, Church of England Moral Wezfare Council, The Family in ConTEMPORARY Society (1958), where world population problems are considered at length. For United:
} 
problem is stated dramatically in the United Nations publication, The Future Growt/h of World Population, where the author points out that whereas the human race took 200,000 years to reach $2,500,000,000$, it will take only thirty years to add another $2,000,000,000$. If the present rate of increase continues, within 600 years, only one square meter of earth will be left for each person to live on. In I950, the world population was $2,500,000,000$; by 1958 , it had reached 2,800,000,000; by 1980 , a population of $4,280,000,000$ is forecast. The world population is expected to double within the next fifty to sixty years, and if current estimates are correct, a world population of between 6,000,000,000 and 7,000,000,000 can be expected by the end of the century.

Population growth is a world-wide phenomenon, but it is taking place much faster in the undeveloped countries of Asia, Africa, and tropical South America than in the advanced countries of Europe and even, in some cases, the United States. ${ }^{65}$ In some places, such as:-Puerto Rico, the annual rate of increase is about three per cent, compared with that of the United States in 1954 of $\mathrm{I} .8$ per cent. In Africa from I95I to I955, the population was increasing annually at a rate of 2.2 per cent; in Asia as a whole, at a rate of $\mathrm{I} .7$ per cent, although it was higher for individual countries. This is to be compared with a 0.7 per cent annual rate of increase for Europe. ${ }^{06}$ Highest rate of increase among the developed countries is shown by the United States, where a population estimated at $166,000,000$ in 1955 is expected to reach 204,000,000 by 1970. Europe does not reflect this pattern of increase, the $5 \mathrm{x}, 000,000$ population of the United Kingdom, for example, being expected to be only 53,700,000 by r970. France's population of $43,300,000$ will be $47,400,000$ in that year. By contrast, countries such as Mainland China and India will increase from 600,000,000 to $799,000,000$ and from $386,000,000$ to $504,000,000$, respectively, in the same period.

Industrial and agricultural revolutions have contributed to this swift growth, but the primary cause is the reduction of disease and a fall in the death rate. Modern medical science has made decline in mortality an almost universal phenomenon, the only exception being Middle Africa, where physical and cultural obstacles remain to be overcome. ${ }^{67}$ In Puerto Rico, for example, the death rate fell from ir.8 per thousand in 1947 to 7.2 in $1955^{68}$ The scope for further reduction is illustrated when one considers the infant mortality rates in different countries. In Britain, it is now 26.5 per thousand, but in India, despite improvement, it is 200. Countries appear to pass through a fourfold cycle in relation to births and deaths. First, both Nations publications, see the series of Population Studies (ST/SOA/Ser. A), especially U.N. DEp'T op Economic and Soctat Affairs, Determinants and Consequences of Population Trends (ST/SOA/Ser. A/I7) (U.N. Pub. Sales No. I953.XIII.3); U.N. Dep'r of Economic and Social Affairs, The Futurb Growth of World Population (ST/SOA/Ser. A/28) (U.N. Pub. Sales No. I959.XIII.2). The population estimates quoted are taken from these publications.

${ }^{\text {o5 }}$ Ireland is the only country where population has declined over the past fifty years.

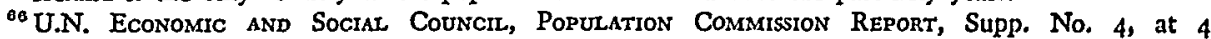
(E/CN.9/144/Rev.I) (1957). See also U.N. Economic aNd Soctal Council, Background Fucts on World Population and Population Trends (E/CN.9/r39) (1957).

${ }^{o 7}$ U.N. Def't of Economic and Soctal Affatrs, The Future Growth of World Population 3-5 (ST/SOA/Ser. A/28) (U.N. Public.Sales. No. r959.XIII.2).

${ }^{\text {eg }}$ U.N. Dep't of Economic and Social Affatrs, Demographic Yearbook (U.N. Pub. Sales No. I956.XIII.5). 
birth and death rates are high; this is followed by a period of high birth rates and falling death rates; then, both birth and death rates fall; and finally, the country passes into a period of low birth and death rates. In the West, stage two of the cycle was not reached until improvements in agriculture and the industrial revolution were under way; but in the East, the decline in death and disease has not been similarly matched. Thus, while the advanced countries can maintain and even raise the standard of life for their increased population, the technologicallyundeveloped countries, where the population by contrast is seriously undernourished, can barely maintain even existing standards, any advance being immediately swallowed up by the increased numbers. In India, for example, the average daily diet is only $I, 590$ calories per person-less than half that of the United States-and two-thirds of the Indian population is underfed. In all, seventy to seventy-five per cent of the world's population does not have enough to eat, seventy per cent of these being concentrated in Asia and eighteen per cent in Africa and parts of South America. ${ }^{60}$

A world in which material resources are so unequally divided, and where the poorest parts are those where the population is increasing most rapidly, raises an acute problem for the Christian conscience. The late Pope Pius XII analyzed the problem in a number of messages and encyclicals; it was discussed at Lambeth in 1958; and an international Protestant study group met at Oxford in April 1959, at the request of the World Council of Churches, to consider the world population problem and the related question of family planning. There is, however, no unanimity amongst Christians as to what action should be taken.

A number of Roman Catholic writers dismiss the population problem as an illusion. They point out that the problem is theoretical rather than practical, since the prophesied catastrophe is dependent on the present rate of expansion of the race continuing into the future. Some resort to ridicule, pointing out that if the egg of every housefly was hatched, the whole surface of the globe would be covered by a mass of flies to a height of three miles within ten years. Again, projecting present population increases into the future, they show that in 5,000 years, the weight of human beings would equal the weight of the earth; in 14,000, the weight of the universe; and, even given stellar emigration, within a few thousand years, the stars themselves would be fully occupied. ${ }^{70}$ This reductio ad absurdum is hardly helpful, any more than is the attitude of those religious writers who maintain that, whatever the figures of expansion, God in due course will provide means of subsistence. Such a total rejection of reason is alien to the tradition of western Roman Catholicism. Others draw comfort from Thomas Doubleday's law, first enunciated in 1837 , stating that nature always counteracts the endangering of the existence of a species by an increase in fertility, and this is especially so when the danger arises from lack of

${ }^{\circ 0}$ Speech of Sir Russell Brain to Annual General Meeting of Family Planning Association in London, June 7, 1958, 7 Famiry Planning 3 (1958).

${ }^{70}$ See Russell, Christian Theology and the Population Problem, 19 The Montr 197, 198 (1958). The article as a whole is a serious discussion of the problem. 
food. Consequently, "the state of depletion or the deplethoric state is favourable to fertility, and ... on the other hand, the plethoric state, or state of repletion, is unfavourable to fertility in the ratio of the intensity of each state."71 Thus, once the general standard of living is raised, the population problem will solve itself..$^{72}$

Of course, the raising of the standard of living to the requisite level will need an intense and concerted international effort, but Roman Catholic social scientists welcome this. They see the population problem as a spur driving mankind forward to the development of a universal community. This positive attitude is evident in the writings of all Roman Catholic thinkers who recognize the urgency of the problem. They stress that individual states have no absolute ownership of territories and natural resources, but hold them in trust for the whole of the human race. Thus, in his very first encyclical, Pope Pius XII declared that the human race has a true unity of nature, a unity of purpose, and a unity of dwelling place on earth, "of whose resources all men can by natural right avail themselves to sustain and develop life."7a The goods created by God should be equitably shared, and wealthier countries are bound by principles of justice and charity to share their resources with countries that are less well provided.

It follows, writes Cardinal Montini, ${ }^{74}$

that a really adequate study of the relations between population and density and means of subsistence must tend to take place on a world-wide scale, while the problem to which they give rise cannot be solved except on that same scale, through the industrious solidarity of all peoples, so that those artificial barriers which divide them being removed, there may arise a more orderly circulation of people, of capital, and of material goods. With this subordination of particular national economic welfare to the common good of the society of nations, frontiers will no longer be valleys which divide, but bridges which unite, and material goods will be free to fulfill their natural function of satisfying everyone's needs.

The Protestant and utilitarian approach of reducing population pressure by spreading contraception as a social policy is condemned not only as a violation of natural law, but as a facile avoidance of the true solution to the problem. "What an error it would be," stated Pius XII in his Christmas message of 1952, "to blame the natural law for the present miseries of the world, when it is clear that these derive from the lack of mutual solidarity of men and peoples."75

${ }^{71}$ SUTherLand, op. cit. Supra note 15, at 197 .

"Doubleday's law in modified form has received recent support in D.E.C. EversLey, Social Theories of Fertility and the Malthusian Debate (1959).

${ }^{78}$ Pius XII, Summi pontificatus, 21 ACra Apostolicae SEdis 426 (1939). See also letter to Archbishop McNicholas, 31 ACTA ApostourcaE SEDIs 69-70 (1948): "The Creator of the Universe has provided all His good gifts primarily for the good of all; consequently, the sovereignty of individual states, however much this is to be respected, ought not to be carried so far that access to the earth's bounty, which is everywhere adequate to support multitudes of human beings, should be denied to needy but worthy persons who have been born elsewhere."

74 Letter to Cardinal Siri on 26th Italian Catholic Social Week held at Palermo, Sicily, Sept. 27, 1953, L'Osservatore Romano, Sept. 28-29, 1953.

${ }_{78} 20$ Acta Apostolicae Sedis (2d ser.) 33, 42 (1953). Msgr. Montini in his letter also rejected attempts to solve population problems by contraception. "Such attempts include, not only the direct killing of the innocent, but also any defrauding of nature's intentions, which, as such, express the will of the Creator Himself." Supra note 74. 
Given, then, a high degree of international cooperation to raise living standards, how many people could the earth support? Estimates vary from 5,000,000,000 on to $16,000,000,000$, Colin Clark calculating in 1953 that the world could support $10,000,000,000$ to $15,000,000,000$ if cultivation and conservation of agricultural land were to reach Dutch standards. ${ }^{76}$ To achieve this, a great technological effort would have to be made by the richer nations. More scientists and agricultural experts would have to be trained and made available, new methods of crop rotation and soil management introduced, and more arable land developed by irrigation, possibly using sea water. Genetic improvement of seed and stock would also help to raise yields. Japan provides an encouraging example of how food production can be raised. During the last sixty years, food supplies have increased faster than the population, and Japan now supports 3.6 times as many people per hectare of cropland than the rest of the Far East, despite the lower fertility of her land. ${ }^{77}$ Mainland China has also made extraordinarily rapid progress, increasing food production by fifty to soo per cent, according to Lord Boyd Orr, in the past three years. He attributes the increase to a substitution of deep ploughing for the old earth-scraping techniques and the use of fertilizers and insecticides. "China," says Lord Orr, "has one quarter of the world's population but seems capable of feeding it well."78 Great areas of forest and scrub land could be cleared and brought under cultivation. ${ }^{79}$ New sources of food supplies could be developed from soil-less agriculture and synthetic manufacture, and the oceans themselves could be utilized for the vegetable substances and fungi that they contain. All this would involve astronomic expenditure, one estimate of the aid required to raise undeveloped countries to a subsistence level being $\$ 18,000,000,000$ per year. Huge as this figure is, it moves into the range of the attainable, when one considers that the military expenditure of the United States and the Soviet Union is already at least five times the amount, ${ }^{80}$ Utilization of solar and atomic energy could speed this revolution considerably.

A supplementary solution to world population problems stressed by Roman Catholic writers is increased opportunity for emigration. In a letter to the American Bishops in I948, Pius XII declared that man had a natural right to emigrate, since God had provided material goods for the use of all. "If then," said the Pope, "in some locality, the land offers the possibility of supporting a large number of people, the sovereignty of the state, although it must be respected, cannot be exaggerated to

${ }^{70}$ Norris, The Population Explosion, IOI AMERICA 242 (I959). It has been estimated that an annual increase of 2.25 per cent per acre in food production was essential to provide a minimum diet for all. World Population and Resources xviii.

${ }^{77}$ See A. F. Zimmerman, Overpopulation 32 (1957). Japan supports seven times as many people per hectare of cropland as the world average and fourteen times as many as the United States.

${ }^{78}$ N.Y. Times, May 14, r959, p. I, col. 5 .

${ }^{70}$ Estimates vary as to how much of the earth is cultivatable, but a common figure is 4,000 million acres, or $12 \%$ of the area. Of this, four-fifths is under cultivation. U.N. DEP'T OF EcoNOMIC AND Social Affairs, Determinants and Consequences of Population Trends i8z (ST/SOA/Ser. A/r7) (U.N. Pub. Sales No. 1953.XII. 3 ). An increase of $25 \%$ is possible, and perhaps more. Once pests were cleared from the tropic zones, cultivation could proceed rapidly.

${ }^{80}$ Norris, supra note 76. Much progress has been made. The F.A.O. Report for 1958-59 notes that while food production rose by $4 \%$ during the period, world population rose $1.6 \%$. 
the point that access to this land is, for inadequate or unjustified reasons, denied to needy and decent people from other nations, whenever this does not hinder the public welfare as measured on honest-weight scales." ${ }^{\text {"11 }}$ Immigration laws should be liberalized, but there are obvious limits to this process. If Australia, for example, were to be peopled by Indians, the maximum that could be absorbed over a long period would be $15,000,000$, which in 1955 represented the annual increase of India's population for only three years. ${ }^{82}$ Again, the capacity of individuals to cross from one culture to another of a radically different nature is clearly limited, and a wholesale immigration would be destructive to the migrants and the social structure of the receiving countries. ${ }^{83}$

Sharing of resources, increase of food supplies, more emigration, are the solutions put forward by Roman Catholics for solving the problems created by world population increase. Protestants and others also support these measures, but emphasize them rather less, because they advocate the spread of family planning as a remedy. ${ }^{84}$ It should be made clear that while family planning in the long run may have a material effect on the increase in population, it cannot be adopted quickly enough to stem the minimum increase of $1,000,000,000$ people that is likely to be achieved by $1980 .{ }^{85}$ This would be so even if the United Nations used its influence to encourage world-wide family planning, but attempts to secure the adoption of such a policy have been blocked by Roman Catholic and communist countries. ${ }^{80}$ Thus in 1952, the World Health Organization dropped a Norwegian proposal to study contraception as part of its official program after opposition from Roman Catholic delegates. ${ }^{87}$ The United Nations has, accordingly, adopted a policy of neutrality on the subject, one of the agreed principles of cooperative action established at the 1954 World Population Conference being to respect different ethical and religious values

\footnotetext{
${ }^{81}$ Letter dated Dec. 24, 1948, I6 Acta Apostolicae Sepjs (2d ser.) 69 (1949). For other statements of Pius XII on migration, see Exsul familia, ig Acta Apostolicae Sedis (2d scr.) 649 (1952).

${ }^{85}$ World Population and Resources i 80 .

${ }^{83}$ For a symposium on emigration problems, see 4 Catholic Law. I03 (1958).

${ }^{84}$ E.g., Karl Barth has stated: "It is the duty of Christians a) to support policies which involve sacrifices by the developed countries on behalf of the underdeveloped ones and b) to advocate policies designed to increase the mobility of capital and labor between the developed and underdeveloped parts of the world." Barth, An Essay in Crusoe Economics-The Economics of Over-Population, in Church or England Moral Weifare Council, op. cit. supta note 64, at 161, 163. For a typical Protestant article advocating family planning, see Gill, The Demographic Explosion, 125 Christian Century 895 (1958).

${ }^{85}$ See Zeegers, The Meaning of the Population Problem of the World, 8 Cross Curnents 22 (1958). See also Simple Methods of Contraception it (I958).

${ }^{80}$ Communism maintains that there is no true population problem, but shortage has been created by the capitalist system. Mainland China adopted a birth-control program in 1956-57, but at the end of the year, it was rumored that it had been abandoned. The last public statement on the Soviet position was made at the Population Conference of 1954, when contraception was condemned. In April I960, however, it was announced from Peiping that Professor Ma Yin-chu had been dismissed from his post as President of Peiping University. The significance of this is that Professor Ma had urged that Mainland China's enormous population was an obstacle to progress. It would seem that Mainland China has now given up controlled population policies and is relying exclusively on increased agricultural production to raise the standard of living. See Mauldin, Population Policies in the Sino-Soviet Bloc, infra pp. 490, 50r-06. For a discussion of the significance of Professor Ma's dismissal see Schattmann, The Case of Mr. Ma Yin-Chut, 63 ThE Listener 8 (1960).
}

${ }^{87}$ N.Y. Times, May 20, 1952, p. 13, col. 3. 
and to promote mutual understanding. This attitude of Roman Catholic countries has been severely criticized, but it is not unreasonable. The United Nations is not a superstate whose majority decisions are binding on all members, but an agency for co-operation between equal partners. If delegate countries take radically conflicting stands on birth control, the only possible line for the United Nations to follow is neutrality. At the same time, advice and the services of experts are available to individual states on request.

A way out of the United Nations dilemma, as far as Roman Catholic countries are concerned, might be offered by the rhythm method of birth control. Roman Catholic theologians are generally agreed that a justifying cause for resorting to rhythm would be the social welfare of a particular community that would benefit by a reduction in population. ${ }^{88}$ This, of course, would mean a widespread public dissemination of knowledge about rhythm, and many moralists consider that communication should be cautious. ${ }^{89}$ On the other hand, these scruples "might well be counterbalanced by the knowledge that the alternative would be use of unnatural means of birth control. As early as r939, Roman Catholic writers were advocating the foundation of Roman Catholic medical bureaus to give rhythm advice, and the need has become very much more urgent since then. ${ }^{90}$ From 1952 to I954, with the help of the United Nations, experiments were, in fact, carried out in India in the use of the rhythm method. Two locations were selected, Lodi colony, an urban middle-class center, and Ramangaram, a small rural town in Mysore. The project ended abruptly in 1954. About seventy-five per cent of the 2,362 married couples in the two centers expressed a desire to learn about family planning, but only 13.6 per cent of the couples in Ramangaram and 28.3 per cent of those in Lodi colony proved capable of learning the method. By the end of March I954, only five per cent and 7.5 per cent, respectively, were known to be following the method regularly. Difficulties reported were a wide variation in women's cycles, mistakes in calculation, and the reluctance of husbands to agree to long periods of abstinence. ${ }^{11}$ On the other hand, Dr. Abraham Stone, who went to India to give instructions in rhythm methods under the auspices of the World Health Organization in r95x, reported a success rate of sixty-five per cent. ${ }^{92}$

India has not confined its activities to propagating the rhythm method, and like Japan, the other eastern country with a population policy, has sought to increase knowledge of contraception. ${ }^{93}$ The possibilities of wider application of rhythm,

${ }^{80}$ See John L. Thomas, Marriage Rhythm Ix7 (1957). See also Pope Pitus XIII on Population, 92 AMIERICA 36 (1954); Fogarty, Is Starvation Inevitable?, 62 CoMmonwent 223 (1955); WiLinam Gibons, The Catholic Value System in Relation to Human Fertility io7-34 (I949). (1937).

${ }^{80}$ For the controversy see 13 The Clergy Rev. I50, I99, 273, 358 (I936); I4 id. 92, 184, 4669

o1 World Population and Resources 219.

${ }^{22}$ N.Y. Times, Oct. 20, 1951, p. I7, col. 6.

${ }^{03}$ Japan has also legalized abortion for medicosocial reasons by the Eugenics Protection Law of Ig 98 ; subsequently amended. The results have been astonishing, 2,679,000 births in 1947 having been redicitd. to $1,563,000$ in 1957 , over $70 \%$ of the reduction being attributable to abortion. The effects on health 
however, remain, and as scientific advance renders it a more reliable and simple method of control, it may well be more widely employed. Its major advantage is that it is the only possible method of international family planning, being acceptable to all major world religions, not only Judaism and Christianity, but also Buddhism, Hinduism, Confucianism, and Islam.

\section{Conclusions}

r. The Roman Catholic Church rejects contraception as contrary to the law of God. The Roman Catholic Church bases its condemnation on the natural law, binding on all men, and not merely on Roman Catholics.

2. The decline of population in England and western Europe is traceable to the widespread use of contraceptives, but population decline is not of necessity an evil.

3. The medical evidence of the effect of contraceptives on health is conflicting.

4. The methods of family planning acceptable to the Roman Catholic Church are limited to abstinence and use of the safe period.

5. Medical evidence shows that the use of the safe period is a reasonably reliable method of birth control but that the margin for error is greater than in appliance control. Its successful employment requires intelligence and self-control.

6. The proposition that an act is contrary to the natural law does not imply that the act should be forbidden by the law of the state. Whether such legislation is desirable is a jurisprudential rather than a theological question, which must be decided in relation to the conditions prevailing in a given community. While Roman Catholics in a democracy have every right to work for legislation outlawing the sale and distribution of contraceptives, the Roman Catholic community in the United States would be wise not to attempt to secure a total legislative ban on contraceptives, but should limit its efforts to securing a policy of state neutrality on the issue and the passing of measures to preserve public morality, commanding the general support of the community. A statute, such as that in Connecticut, that forbids the use of contraceptives violates Roman Catholic principles of jurisprudence.

7. The conflicts of principle between Roman Catholics and Protestants as to whether birth-control advice should be given in tax-supported hospitals are irreconcilable, and only a compromise is possible. The three principles now acted on by the New York City hospitals might well be generally followed:

a. Birth-control advice should be available to any female patient if she wishes to avail herself of it and her health would be jeopardized by pregnancy.

b. Employees of the hospital having religious or moral objections to contraceptive procedures should be excused from participation.

c. Contraceptive advice not required for medical reasons should be left to voluntary agencies and doctors in private practice.

have been deplorable, and the policy may be modified. Sever hundred and sixty-three health centers in Japan give advice on abortion, sterilization, and contraception. See Bronfenbrenner \& Buttrick, Population Control in Japan: An Economic Theory and Its Application, infra pp. 536, 553-56. 
8. Roman Catholic hospitals are justified in imposing conditions of employment that exclude the giving of birth-control advice to patients in the hospital, but such conditions should not extend to a doctor's practice unconnected with the hospital. The association of non-Roman Catholic doctors, outside the hospital, with birthcontrol organizations is no concern of the hospital authorities.

9. The medical experiments now in progress to develop a contraceptive pill, even if successful, will not lessen Roman Catholic-Protestant conflict over birth control, since such a pill is subject to the same condemnation by Roman Catholic theologians as other forms of contraception. The only "pill" acceptable to Roman Catholics would be one to regularize periodicity in women.

10. World population growth presents a challenge to the Christian conscience to secure an intense and concerted international effort to raise living standards. Given such an effort, the prospects for a very considerable increase in world food production are favorable.

II. Increased opportunity for emigration from the more densely to the less densely populated parts of the world would alleviate but not solve world population problems.

I2. Receipt of help under the United States foreign aid program should not be made conditional on the adoption of artificial birth-control policies by the recipient state, nor should foreign aid funds be used to implement such a program, even at the request of the designated state.

13. The United Nations policy of neutrality on the question of contraception is the only one possible in view of the conflicting opinions of member states. Rhythm is the only method of birth control that would be acceptable as a means of international family planning. 